\title{
Erratum to: Back to the Grindstone? The Archaeological Potential of Grinding-Stone Studies in Africa with Reference to Contemporary Grinding Practices in Marakwet, Northwest Kenya
}

\author{
Anna C. Shoemaker • Matthew I. J. Davies • Henrietta L. Moore
}

Published online: 18 September 2017

(C) Springer Science+Business Media, LLC 2017

\section{Erratum to: Afr Archaeol Rev}

https://doi.org/10.1007/s10437-017-9264-0

The original version of this article unfortunately contained a mistake. The nomenclature "Eragrostis tei" in the body should be "Eragrostis tef."

M. I. J. Davies

African Studies Research Center, University College London, London, UK

\section{H. L. Moore} Institute for Global Prosperity, University College London, London, UK 